\title{
Variation of Lactate Dehydrogenase Isozymes in Angelfish (Pterophyllum scalare) according to Acute Environmental Change
}

Chang-Su $\mathrm{An}^{\dagger}$, Sung Kyu $\mathrm{Cho}^{1+}$ and Jung Joo Yum² ${ }^{2}$

\author{
Department of Quality Assurance, SK Chemicals Life Science Biz., Osan 447-320, Republic of Korea \\ ${ }^{1}$ Industrial Science Research Institute, Cheongju University, Cheongiu 360-764, Republic of Korea \\ ${ }^{2}$ Department of Life Science, Cheongju University, Cheongju 360-764, Republic of Korea
}

Received December 20, 2009 /Accepted February 17, 2010

\begin{abstract}
In this study, the properties and gene expression of the lactate dehydrogenase (EC 1.1.1.27, LDH) isozyme were studied in angelfish (Pterophyllum scalare) - known for their adaptation to the low oxygen environment of the tropics - which were acclimated to acute temperature change $\left(27 \pm 0.5 \rightarrow 18 \pm 0.5^{\circ} \mathrm{C}\right)$ and dissolved oxygen (DO) change $(6 \pm 1 \rightarrow 18 \mathrm{ppm})$ for 2 hours. The properties of the LDH isozymes were confirmed in the native-polyacrylamide gel electrophoresis, Western blot analysis and enzyme activity measurement. Liver- and eye-specific $L d h-C$ gene were expressed in liver, eye and brain tissues. Through Western blot analysis, the $\mathrm{LDH}_{4}$ isozyme was shown to have a more cathodal mobility relative to the $\mathrm{B}_{4}$ isozyme. In the liver tissue, the $\mathrm{LDH} \mathrm{A}_{4}$ isozyme increased with temperature drop while the $B_{4}$ isozyme decreased. The LDH $A_{4}$ and $C_{4}$ isozymes increased with DO increment, while the $\mathrm{B}_{4}$ isozyme decreased. In the eye tissue, the $\mathrm{LDH} \mathrm{A}_{4}$ and $\mathrm{B}_{4}$ isozymse increased with temperature drop while the $\mathrm{C}_{4}$ isozyme decreased. The $\mathrm{LDH} \mathrm{A}_{4}$ and $\mathrm{B}_{4}$ isozymes increased with DO increment, but the $\mathrm{C}_{4}$ isozyme and isozymes including the subunit $\mathrm{C}$ decreased. In the heart tissue, $\mathrm{LDH}$ activity increased with DO increment, as well as the LDH $\mathrm{B}_{4}$ isozyme. In the brain tissue, the LDH $\mathrm{A}_{4}$ and $\mathrm{B}_{4}$ isozymes increased with temperature drop. The LDH $\mathrm{B}_{4}$ isozyme increased with DO increment. Accordingly, since the liver- and eye-specific $L d h$ - $C$ are influenced by changes in DO and the LDH $B_{4}$ and $C_{4}$ isozymes are relatively controlled in the liver and eye tissues, the $C_{4}$ isozyme can be considered to have a lactate oxidase function.
\end{abstract}

Key words : Angelfish (Pterophyllum scalare), lactate dehydrogenase, isozyme, temperature, DO

\section{서 론}

대부분의 어류는 넓은 온도 범위에서 생존할 수 있는데 이 는 세포내 기질농도의 변화, 효소반응에 영향을 미치는 조절 물질농도의 변화, 유전자 조절에 의한 효소활성 또는 동위효 소의 변화 등으로 온도변화에 순응된 후 에너지대사가 일정하 게 유지되기 때문이다[16,31]. 온도는 생화학 반응에 영향을 주는 비생물학적인 요인으로 항온동물에 물리, 생화학적으로 큰 영향을 주어 효소반응 속도, 확산률, 막 유동성 및 단백질 구조를 변형시킨다[14,39]. 온도변화를 준 후 긴 주기 동안 유 지하면 항온동물은 효소변화가 유도되어 대사에 대한 온도의 영향이 완화된다. 어류에 있어서 온도순응은 서식처의 계절적 온도변화에도 불구하고 같은 운동능력 및 대사율을 유지하도 록 하여준다[12,15]. 온도순응은 해당과정 및 미토콘드리아 효 소의 상대적 활성변화를 수반하며 효소활성의 변화는 효소합 성에서 온도의 직접적 영향을 받아 유도되거나 온도에 의한 대사불균형에 의해 유도된다[12,14].

\footnotetext{
${ }^{\dagger}$ Co-first author

*Corresponding author

Tel : +82-43-229-8527, Fax : +82-43-229-8525

E-mail : iivum@cju.ac.kr
}

산소에 의해 조절되는 유전자 발현은 모든 진핵식물 및 동 물세포에서 볼 수 있으며[28], 척추동물의 세포에서 산소농도 는 에너지대사, 혈관형성, 적혈구생성, 면역반응 및 유전자전 사 등을 포함하는 단백질 생성과정의 유전자발현에 영향을 준다[13,28,32]. 에너지대사와 관련된 동위효소의 변화에 대한 연구는 동위효소 형태가 처음 발견되었고 생체 내 에너지대사 에서 중요한 위치를 차지하고 있는 젖산탈수소효소(EC 1.1.1.27, lactate dehydrogenase, $\mathrm{LDH}$ )를 대상으로 많은 연구들이 이루 어졌다[8,22,25,27,40].

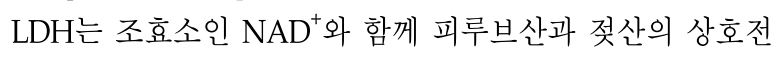
환을 촉매하는 효소로서 에너지대사에서 중요한 위치를 차지 한다. 또한 이들 기질수준은 산소 유용성에 기초한다. $\mathrm{LDH}$ 는 사량체이며 척추동물에서 $\mathrm{A}, \mathrm{B}$ 및 $\mathrm{C}$ 의 다른 하부단위체를 갖 는다[32]. 하부단위체들은 단일유전자, $L d h-A, L d h-B$ 및 $L d h-C$ 에 의해 암호화되며 고등 진핵세포에서 산소 유용성에 기초하 여 활성을 갖거나 억제된다[5,32]. $\mathrm{LDH} \mathrm{A}$ 동위효소는 혐기적 조건하에서 선택적으로 피루브산을 젖산으로 전환하는 pyruvate reductase로 알려져 있고 생리학적 저산소 환경에 노출 되어 있는 골격근 같은 조직에서 우세하게 나타난다. 반면에 $\mathrm{LDH} \mathrm{B}_{4}$ 동위효소는 호기적 조건하에서 젖산을 피루브산으로 
전환하는 lactate oxidase로 심근 같은 조직에서 우세하게 나타 난다[41]. 조직 내 피루브산 농도가 높을 경우, 호기적 조직에 서는 젖산 축적이 제한되고 $\mathrm{LDH} \mathrm{B} \mathrm{B}_{4}$ 동위효소의 기능이 억제 되며, 혐기적 조직에서는 $\mathrm{LDH} \mathrm{A} 4$ 동위효소의 활성이 증가되 어 젖산이 축적된다[2]. 또한 저산소 조건에 서식하는 icefish 심장 $\mathrm{LDH} \mathrm{B} \mathrm{B}_{4}$ 동위효소의 경우 생리, 생화학적으로 환경에 적 응되어 구조 및 역학적 특성이 골격근에서 주로 나타나는 $\mathrm{A}_{4}$ 동위효소와 유사하게 나타나기도 한다[10]. 따라서 LDH 동위 효소의 기능적인 특성은 환경요인에 대한 순응과정에서 대사 생리학적인 연구에 중요한 역할을 수행하고 있다. $\mathrm{LDH} \mathrm{C} \mathrm{C}_{4}$ 동위효소는 하등한 경골어류의 경우 여러 조직에서 나타나고 [20,24,36], 고등한 경골어류에서는 눈, 뇌 및 간 조직[37], 포유 류와 조류의 경우 정소에서 나타난다[11]. $\mathrm{LDH} \mathrm{C} \mathrm{C}_{4}$ 동위효소의 전기영동상은 눈 조직의 경우 강한 음하전을 띠어 양극 쪽에 서 eye-specific $\mathrm{LDH} \mathrm{C}_{4}$ 동위효소가 나타나고, 간 조직의 경우 강한 양하전을 나타내어 음극 쪽에서 liver-specific $\mathrm{LDH} \mathrm{C} \mathrm{C}_{4}$ 동위효소가 나타난다[18,30,36,37,42]. 눈과 간 조직에서 LDH $\mathrm{C}_{4}$ 동위효소가 동시에 나타나는 어류는 두 조직에서 모두 음 하전을 띠는 경우[3,19], 두 조직에서 모두 양하전을 띠는 경우 [36,37] 및 두 조직에서 하전이 각기 다른 경우[17,29]가 보고되 어 있다. 그러나 진화상의 일부 중간어류군은 $L d h-C$ 유전자가 발현되지 않는 것으로 보고되었다[29]. 그러나 어류 $\mathrm{LDH} \mathrm{C} \mathrm{C}_{4}$ 동위효소의 기능은 포유류나 다른 동위효소들에 비하여 상대 적으로 확실하게 밝혀져 있지 않다[2,6]. 이러한 LDH 동위효 소들의 기능적인 특성은 환경에 순응하는 생명체의 대사 생리 학적인 연구에서 중요시 되고 있다. 온도 및 $\mathrm{pH}$ 영향에 따른 $\mathrm{LDH}$ 의 역학적 특성[22,26] 및 구조와 기능에 대한 연구[27]는 대부분 in vitro에서 골격근 및 심장 같은 특정 조직에서 수행 되었고, 일정한 두 환경조건에 완전히 순응시킨 후 $\mathrm{LDH}$ 동위 효소의 특성이 비교되어 있으며[34,35], 발생 단계에서의 시간 별 $\mathrm{LDH}$ 특성만이 일부 연구되었을 뿐[38] 인위적인 환경조건 에 대한 순응과정에서 $\mathrm{LDH}$ 동위효소의 특성에 관한 연구는 미흡하다.

따라서 본 연구는 급격한 환경변화 시 생명체가 적응하는 초기과정에서 나타나는 대사를 확인하는 연구의 일환으로 열 대 저산소 상태에 적응되어 있고 liver- 및 eye-specific $L d h-C$ 유전자가 모두 발현되는 angelfish를 재료로 생리 및 생화학적 방법을 이용하여 대사상 $\mathrm{LDH}$ 동위효소들의 특성을 연구하고 자 하였다.

\section{재료 및 방법}

\section{실험 재료}

농어목 시클리드과(Perciformes, Cichlidae)에 속하는 angelfish (Pterophyllum scalare)는 인천광역시 신흥동 한일어조 원에서 구입하여 사용하였다. Pyruvic acid, acrylamide,
$\mathrm{N}, \mathrm{N}^{\prime}$-methylene-bis-acrylamide, $\mathrm{N}, \mathrm{N}, \mathrm{N}^{\prime}, \mathrm{N}^{\prime}$-tetramethylethylenediamine (TEMED), DL-lactic acid, nitro blue tetrazolium (NBT), phenazine methosulfate (PMS), nicotinamide adenine dinucleotide $\left(\mathrm{NAD}^{+}\right)$, NAD reduced form (NADH) 및 anti-rabbit IgG (peroxidase conjugate)는 Sigma사의 제품을 사 용하였고, Coomassie brilliant blue G-250은 Fluka사 제품을 사용하였으며, 나머지 시약은 GR (guaranteed reagent)급을 사용하였다.

\section{사육 및 실험 조건}

Angelfish는 $\mathrm{pH} 7 \pm 0.5$, 온도 $27 \pm 0.5^{\circ} \mathrm{C}$ 및 $\mathrm{DO} 6 \pm 1 \mathrm{ppm}$ 인 조건의 수조 $(90 \times 30 \times 45 \mathrm{~cm})$ 내에서 사육한 후 $9 \pm 1 \mathrm{~cm}$ 정도 크기의 성체를 사용하였다. 기초양어수는 상수의 염소를 제거 시킨 후 사용하였고 수중전기펌프(ID-10, Young il Co., Daegu, Korea)를 이용한 여과로 정화하였다. 먹이는 2회/1일 주기로 사료(Pro Teich 2, JBL GmbH Co., Neuhofen, Germany)를 공급하였다. $\mathrm{pH}$ 는 $\mathrm{pH}$ 상승제 및 하강제(Fritz Chem. Co., Dallas, TX)를 사용하여 $\mathrm{pH} 7 \pm 0.5$ 를 유지하였고 온도는 온도 조절기가 부착된 가열기(Jäger LZRH 150, EHEIM GmbH \& Co. KG, Deizisau, Germany)와 투입냉각기(EYELA ECS-0, Rikakikai Co., Ltd., Tokyo, Japan)를 사용하여 조절하였다. $\mathrm{DO}$ 는 전기기포발생기(DK-8000, Dae Kwang Co., Korea) 및 조절기가 장착된 고압산소탱크를 사용하여 조절하였고 $\mathrm{DO}$ meter (DO-14P, TOA Electronics Ltd., Tokyo, Japan)로 측정 하였다. 온도조건 변화 시 $\mathrm{pH} 7 \pm 0.5$, 온도 $27 \pm 0.5^{\circ} \mathrm{C}$ 및 $\mathrm{DO}$ $6 \pm 1 \mathrm{ppm}$ 에서 어류를 순응시킨 후 온도조건만 $27 \pm 0.5^{\circ} \mathrm{C}$ 에서 $18 \pm 0.5^{\circ} \mathrm{C}$ 로 변화시켰고, $\mathrm{DO}$ 조건 변화 시 $\mathrm{DO}$ 조건만 $6 \pm 1 \mathrm{ppm}$ 에서 $18 \mathrm{ppm}$ 으로 변화시켰으며, 2시간 순응시킨 후 즉시 도살 하여 실험하였다.

\section{세포기질 및 미토콘드리아 LDH 분리}

Angelfish 각 조직의 세포기질 $\mathrm{LDH}$ 와 미토콘드리아 $\mathrm{LDH}$ 는 Schnaitman 등의 방법[33]을 활용하여 분리하였다. 환경조건을 변화시켜 사육한 angelfish는 즉시 도살하여 골 격근, 심장, 간, 눈 및 뇌 조직을 떼어내었다. 때어낸 각 조직 은 $4^{\circ} \mathrm{C}$ 로 유지시킨 $0.25 \mathrm{M}$ sucrose, $5 \mathrm{mM}$ potassium phosphate buffer ( $\mathrm{pH}$ 6.5)를 4 배(v/w) 또는 8 배 가하여 얼음에 채운 Dounce homogenizer 및 Potter-Elvehjem homogenizer 로 파쇄 하였다. 파쇄물은 $4^{\circ} \mathrm{C}, 1,000 \times g(20$ PR-52D, Hitachi Koki Co. Ltd., Tokyo, Japan)에서 15분간 2회 원심분리 하여 침전된 핵을 제거하였고, 상등액을 $4^{\circ} \mathrm{C}, 10,000 \times$ g에서 원심 분리 하여 상등액과 침전된 미토콘드리아 분획을 얻었다. 그 상등액은 $4^{\circ} \mathrm{C}, 20,000 \times g$ 에서 30 분간 원심분리 후 상등액을 취하여 세포기질의 $\mathrm{LDH}$ 시료로 사용하였다. 순수한 미토콘 드리아를 얻기 위하여 미토콘드리아 분획을 $0.25 \mathrm{M}$ sucrose, $5 \mathrm{mM}$ potassium phosphate buffer ( $\mathrm{pH}$ 6.5)로 현탁시킨 후, 
$4^{\circ} \mathrm{C}, 10,000 \times g$ 에서 10 분간 원심분리 하였고, 동일 buffer를 사용해서 상등액에 $\mathrm{LDH}$ 활성이 나타나지 않을 때까지 세척 하여 순수한 미토콘드리아 분획을 얻었다. 침전된 미토콘드 리아는 $175 \mathrm{mM} \mathrm{NaCl}$ 를 포함하는 $0.25 \mathrm{M}$ sucrose, $5 \mathrm{mM}$ potasium phosphate buffer ( $\mathrm{pH}$ 6.5)를 10배(v/w) 또는 20배 $(\mathrm{v} / \mathrm{w})$ 가하여 현탁시킨 후 $4^{\circ} \mathrm{C}, 20,000 \times \mathrm{g}$ 에서 30 분간 원심 분리 한 다음 얻어진 상등액을 미토콘드리아 $\mathrm{LDH}$ 시료로 사용하였다.

\section{Native-polyacrylamide gel 전기영동(native-PAGE)}

Native-PAGE는 Davis의 방법[9]으로 실시하였다. 전기영 동은 $7.5 \% \mathrm{~T}, 2.67 \% \mathrm{C}$ acrylamide separation gel과 $3 \% \mathrm{~T}$, $2.67 \% \mathrm{C}$ acrylamide stacking gel을 만들어 polyacrylamide vertical slab system (SE250, Hoefer Sci. Instr., San Francisco, CA)에서 실시하였다. $50 \%$ Sucrose와 $0.05 \%$ bromophenol blue 용액을 1:1(v/v)로 가한 시료를 gel 상부의 홈에 넣은 후, $5 \mathrm{mM}$ Tris-glycine buffer (pH 8.3)를 사용하여 $100 \mathrm{~V}$ 에서 20 분간 전개한 다음, $200 \mathrm{~V}$ 에서 2시간 10 분간 냉각수순환장치 (EYELA CA-1100, Rikakikai Co. Ltd., Tokyo, Japan)를 사용 하여 $4^{\circ} \mathrm{C}$ 에서 전기영동 하였다. 효소염색은 Whitt의 방법[42] 에 따라 $\mathrm{DL}$-lactate, NBT, PMS, 및 $\mathrm{NAD}^{+}$혼합용액에 gel을 넣어 $37^{\circ} \mathrm{C}$ 에서 염색한 후 $15 \%$ 초산용액으로 고정하였다. $\mathrm{Gel}$ 상에 나타난 $\mathrm{LDH}$ 동위효소의 활성정도는 이미지분석프로그 램(Viber Lourmat Bio profil, BIO-ID++ V.96)을 사용하여 분 석하였다.

\section{Western blot analysis}

Angelfish 눈 조직 추출액을 native-PAGE한 후 gel상의 단 백질은 $15 \mathrm{mM}$ Tris-glycine buffer (pH 8.3) 및 semi-dry transfer system (Trans-Blot SD cell, Bio-Rad Lab. Inc., Hercules, $\mathrm{CA}$ )을 사용하여 $25 \mathrm{~V}$ 에서 30 분간 nitrocellulose membrane (Trans-Blot Transfer Medium, Bio-Rad Lab. Inc., Hercules, $\mathrm{CA})$ 에 옮겼다. 단백질이 옮겨진 membrane을 $5 \%$ skim milk /TBS (0.01 M Tris buffered saline, pH 7.5) 용액에 넣고 $25^{\circ} \mathrm{C}$ 에서 1 시간 동안 blocking시킨 후 TBS용액에서 10분간씩 3회 세척하였다. $5 \%$ Skim milk/TBS를 사용하여 1:1,000으로 희석 한 $\mathrm{LDH} \mathrm{A} \mathrm{A}_{4}$ 동위효소에 대한 항체 및 1:500으로 희석한 $\mathrm{B}_{4}$ 동위 효소에 대한 항체 용액에 membrane을 넣고 $25^{\circ} \mathrm{C}$ 에서 1 시간 동안 shaking 시킨 후 TBS용액으로 10 분간씩 2회 세척하여 membrane에 결합하지 않은 각 1 차 항체를 씻어주었다. Anti-rabbit IgG (2차 항체)를 $5 \%$ skim milk/TBS를 사용하여 1:1,000으로 희석시킨 용액에 membrane을 넣고 1 시간 동안 shaking시킨 후 항원과 결합하지 않은 2 차 항체를 $\mathrm{TBS}$ 용액으 로 10 분간씩 3회 세척하였다. Chloronaphtol 및 $\mathrm{H}_{2} \mathrm{O}_{2}$ 의 혼합 액으로 반응시킨 후 증류수로 세척하여 반응을 정지시킨 다음 밴드를 확인하였다.

\section{단백질 정량}

단백질은 Bradford의 방법[4]에 의하여 정량하였다. 정량시 약은 Coomassie brilliant blue G-250 $100 \mathrm{mg}$ 을 $85 \% \mathrm{H}_{3} \mathrm{PO}_{4}$ $100 \mathrm{ml}$ 에 세게 저어주면서 섞은 후, $95 \%$ 에탄올 $50 \mathrm{ml}$ 를 첨가 한 다음, $4^{\circ} \mathrm{C}$ 증류수로 11 를 만들어 사용하였다. 단백질 정량 시 분광광도계(UV-160A, Shimadzu Co. Ltd., Kyoto, Japan)를 사용 $595 \mathrm{~nm}$ 에서 흡광도를 측정하였고 $\mathrm{BSA}$ 를 정량 표준단백 질로 사용하였다.

\section{$\mathrm{LDH}$ 활성 측정}

$\mathrm{LDH}$ 활성은 $1.50 \mathrm{mM}$ 피루브산과 $0.14 \mathrm{mM} \mathrm{NADH}$ 를 함유 하는 $0.1 \mathrm{M}$ potassium phosphate buffer $(\mathrm{pH}$ 6.85) $3 \mathrm{ml}$ 에 시료를 넣은 후 $\mathrm{NADH}$ 로부터 $\mathrm{NAD}^{+}$로 산화되는 정도를 분광 광도계를 사용하여 $25^{\circ} \mathrm{C}, 340 \mathrm{~nm}$ 에서 측정하였다. 효소활성 의 단위 1 unit는 1 분간 기질 $1 \mu \mathrm{mole}$ 을 생성물로 전환시키는 데 필요한 효소의 양으로 정하였다.

\section{결과 및 고찰}

\section{Angelfish LDH 동위효소들의 동정}

Angelfish의 골격근, 심장, 간, 눈 및 뇌 조직 세포기질 $\mathrm{LDH}$ 를 전기영동 한 결과(Fig. 1), 눈 조직에서 가장 많은 $\mathrm{LDH}$ 동위 효소들이 나타났다. 따라서 각 $\mathrm{LDH}$ 동위효소들을 동정하기 위하여 눈 조직을 $\mathrm{LDH} \mathrm{A} \mathrm{A}_{4}$ 동위효소에 대한 항체[7] 및 $\mathrm{B}_{4}$ 동위 효소에 대한 항체[6]로 Western blotting시켰다(Fig. 2). 그 결 과 $\mathrm{LDH} \mathrm{\textrm {A } _ { 4 }}$ 동위효소는 $\mathrm{B}_{4}$ 동위효소보다 음극 쪽에 나타났다. $\mathrm{LDH} \mathrm{C}_{4}$ 동위효소의 경우 간 조직에서 liver-specific $\mathrm{LDH} \mathrm{C}_{4}$ 동위효소가 양하전을 띠어 음극 쪽에서 나타났고 눈 조직에서 eye-specific $\mathrm{LDH} \mathrm{C}_{4}$ 동위효소가 음하전을 띠어 양극 쪽에서 나타났다(Fig. 1). 본 실험 결과는 starch gel 전기영동 시 같은

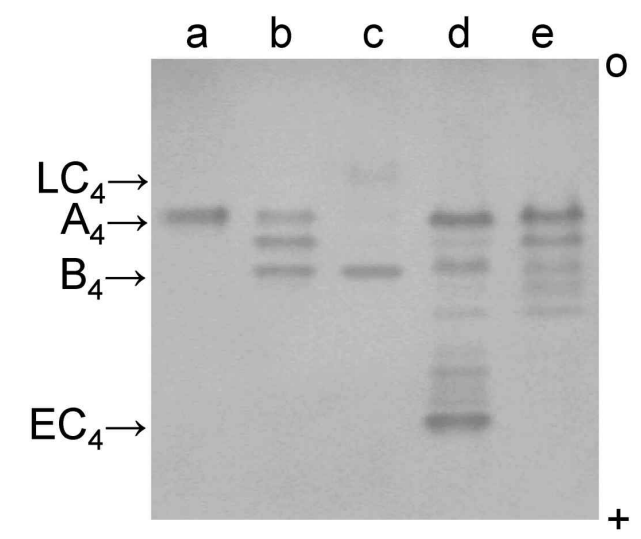

Fig. 1. Native-polyacrylamide gel electrophoresis zymograms of cytosolic LDH isozymes in angelfish ( $P$. scalare). a, Skeletal muscle; $b$, heart; $c$, liver; $d$, eye; e, brain; $\mathrm{A}_{4}, \mathrm{LDH}$ $\mathrm{A}_{4}$ isozyme; $\mathrm{B}_{4}, \mathrm{LDH} \mathrm{B}_{4}$ isozyme; $\mathrm{LC}_{4}$, liver-specific $\mathrm{LDH}$ $\mathrm{C}_{4}$ isozyme; $\mathrm{EC}_{4}$, eye-specific $\mathrm{LDH} \mathrm{C}_{4}$ isozyme; o, origin. 


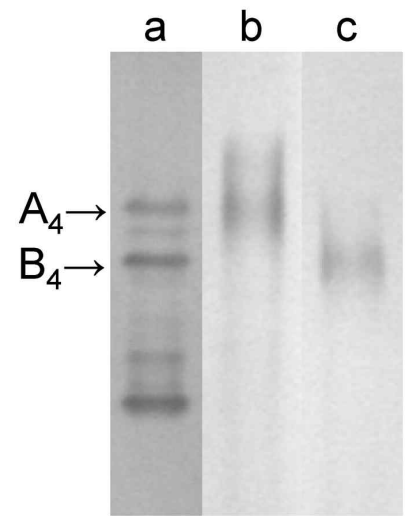

Fig. 2. Western blot analysis of the LDH isozymes in eye from angelfish ( $P$. scalare). a, Native-polyacrylamide gel electrophoresis zymograms of the LDH isozymes in eye; $b$, Western blotting of the LDH $\mathrm{A}_{4}$ isozyme; $\mathrm{c}$, Western blotting of the $\mathrm{LDH} \mathrm{B}_{4}$ isozyme.

종의 간 조직에서 liver-specific $\mathrm{LDH} \mathrm{C} \mathrm{C}_{4}$ 동위효소가 나타나지 않았던 Holt와 Leibel의 결과[17]와 달랐는데 이는 전기영동 gel 성분의 차이에 기인한다고 생각된다.

환경 변화에 따른 조직별 세포기질 $\mathrm{LDH}$ 동위효소들의 변화 골격근 조직은 환경변화에 영향을 받지 않고 $\mathrm{LDH} \mathrm{A}$ 동위 효소만 나타났다(Table 1). 심장 조직은 $\mathrm{LDH} \mathrm{B}$ 동위효소가 $\mathrm{A}_{4}$ 동위효소보다 높은 활성을 보였으며, 기본조건과 온도변화

Table 1. Relative activity (\%) of cytosolic LDH isozymes in angelfish ( $P$. scalare)

\begin{tabular}{|c|c|c|c|c|}
\hline LDH Condition & & Basic & Temperature & $\mathrm{DO}$ \\
\hline Skeletal muscle & $\mathrm{A}_{4}$ & 100 & 100 & 100 \\
\hline \multirow{3}{*}{ Heart } & $\mathrm{A}_{4}$ & 26.1 & 27.2 & 24.9 \\
\hline & $\mathrm{A}_{2} \mathrm{~B}_{2}$ & 36.5 & 37.3 & 27.1 \\
\hline & $\mathrm{B}_{4}$ & 37.5 & 35.5 & 48.0 \\
\hline \multirow{4}{*}{ Liver } & $\mathrm{C}_{4}$ & 28.1 & 27.3 & 54.3 \\
\hline & $\mathrm{A}_{4}$ & - & 26.8 & 26.2 \\
\hline & $\mathrm{A}_{2} \mathrm{~B}_{2}$ & - & 14.1 & - \\
\hline & $\mathrm{B}_{4}$ & 71.9 & 31.7 & 19.5 \\
\hline \multirow{7}{*}{ Eye } & $\mathrm{A}_{4}$ & 26.6 & 49.0 & 47.0 \\
\hline & $\mathrm{A}_{2} \mathrm{~B}_{2}$ & 5.1 & - & - \\
\hline & $\mathrm{B}_{4}$ & 12.6 & 20.7 & 32.8 \\
\hline & C hybrid & 4.3 & - & - \\
\hline & C hybrid & 8.8 & - & - \\
\hline & C hybrid & 9.4 & - & - \\
\hline & $\mathrm{C}_{4}$ & 33.2 & 30.2 & 20.2 \\
\hline \multirow{5}{*}{ Brain } & $\mathrm{A}_{4}$ & 38.8 & 41.3 & 37.8 \\
\hline & $\mathrm{A}_{2} \mathrm{~B}_{2}$ & 22.5 & 24.0 & 20.0 \\
\hline & $\mathrm{B}_{4}$ & 14.7 & 20.4 & 42.2 \\
\hline & C hybrid & 12.6 & 9.2 & - \\
\hline & C hybrid & 11.4 & 5.0 & - \\
\hline
\end{tabular}

를 준 결과는 비슷하였지만, $\mathrm{DO}$ 증가 시 $\mathrm{LDH} \mathrm{B}$ 동위효소가 두 조건보다 더 강한 활성을 보였다. 이처럼 온도 및 $\mathrm{DO}$ 를 변화시켰을 때 나타나는 조직 특이성은 조직 내 각 $\mathrm{LDH}$ 동위 효소들의 기능적인 특성이 서로 다르다는 것을 나타내고 $\mathrm{LDH}$ 동위효소가 환경조건에 민감하게 반응함을 알 수 있다. 간 조 직에서는 음극 쪽에 liver-specific $\mathrm{LDH} \mathrm{C} \mathrm{C}_{4}$ 동위효소가 나타났 는데 이는 모래무지, 붕어 및 참마자 등 잉어목 어류의 경우 [30]와 같았다. 특이하게 기본조건에서 $\mathrm{LDH} \mathrm{B}_{4}$ 동위효소는 나타난 반면 $\mathrm{A}_{4}$ 동위효소는 나타나지 않았다. 그러나 온도 저 하 시 $\mathrm{LDH} \mathrm{A} \mathrm{A}_{4}$ 동위효소 및 이질사량체가 나타났고 $\mathrm{B}_{4}$ 동위효 소는 현저히 감소하였다. 특히 $\mathrm{DO}$ 증가 시 $\mathrm{LDH} \mathrm{B} \mathrm{B}_{4}$ 동위효소 는 감소하고 $\mathrm{C}_{4}$ 동위효소는 상대적으로 증가하였는데, 이는 $\mathrm{DO}$ 증가 시 적응하는데 있어서 $\mathrm{LDH} \mathrm{B}_{4}$ 동위효소보다 $\mathrm{A}_{4}$ 및 $\mathrm{C}_{4}$ 동위효소가 더 중요하게 작용함을 시사한다. 눈 조직에서 는 꺽지 및 쏘가리 등 농어목 어류의 경우[30]와 같이 양극 쪽에 eye-specific $\mathrm{LDH} \mathrm{C} \mathrm{C}_{4}$ 동위효소 및 여러 C hybrid 동위효

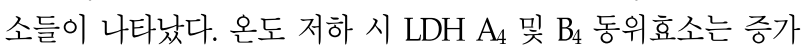
되나 $\mathrm{C}_{4}$ 동위효소는 조금 감소하였고, $\mathrm{DO}$ 증가 시 $\mathrm{C}_{4}$ 동위효 소는 감소한 반면 $\mathrm{A}_{4}$ 및 $\mathrm{B}_{4}$ 동위효소는 증가하였으며, $\mathrm{C}$ hybrid 및 이질사량체는 나타나지 않았다. 이는 온도 저하 시 생리적 대사가 $\mathrm{LDH} \mathrm{A}_{4}$ 및 $\mathrm{B}_{4}$ 동위효소에 의해 조절되지만, $\mathrm{DO}$ 증가 시는 $\mathrm{A}_{4}$ 동위효소는 증가되나 간 및 눈 조직에서 $\mathrm{B}_{4}$ 및 $\mathrm{C}_{4}$ 동위효소가 서로 상대적으로 활동하여 조절되어지는 것을 나타낸다. Angelfish는 아마존 Cichlids의 한 종으로 간 및 눈 조직에서 모두 $\mathrm{LDH} \mathrm{C}_{4}$ 동위효소가 나타나며[1], 또한 liver- 및 eye-specific $\mathrm{LDH} \mathrm{C}_{4}$ 동위효소는 같은 $L d h$ - $C$ 유전자 에서 암호화되는 동질단백질로 여겨지고 있다[1,23]. 마지막으 로 뇌 조직은 기본조건에서 $\mathrm{LDH} \mathrm{\textrm {A } _ { 4 }}$ 동위효소가 $\mathrm{B}_{4}$ 동위효소 보다 강한 활성을 보였고, 환경변화 시 $\mathrm{A}_{4}$ 동위효소는 변화되 지 않고 $\mathrm{B}_{4}$ 동위효소가 증가되었다. 특히 $\mathrm{DO}$ 증가 시 심장 조직처럼 $\mathrm{LDH} \mathrm{B}_{4}$ 동위효소가 $\mathrm{A}_{4}$ 동위효소보다 강한 활성을 나타냈고 하부단위체 $\mathrm{C}$ 는 나타나지 않았다(Table 1). 따라서 심장 및 뇌 조직은 환경변화 시 $\mathrm{LDH} \mathrm{B} \mathrm{B}_{4}$ 동위효소가 증가되어 조절되었고, liver- 및 eye-specific $L d h-C$ 는 DO 변화에 의해 영향을 받으며, 간 및 눈 조직에서 $\mathrm{LDH} \mathrm{A} \mathrm{A}_{4}$ 동위효소는 증가되 고 $\mathrm{B}_{4}$ 및 $\mathrm{C}_{4}$ 동위효소가 서로 상반되게 조절되는 것으로 나타 나 $\mathrm{C}_{4}$ 동위효소는 $\mathrm{B}_{4}$ 동위효소와 유사하게 lactate oxidase로서 기능을 나타내는 것으로 사료된다.

\section{미토콘드리아의 $L D H$ 동위효소}

Angelfish의 미토콘드리아 $\mathrm{LDH}$ 를 전기영동 한 결과 모든 조직에서 세포기질 LDH (Fig. 1)에 비해 활성이 낮게 나타났 으며, 동질사량체인 $\mathrm{LDH} \mathrm{A}_{4}$ 및 $\mathrm{B}_{4}$ 동위효소만 나타나고 $\mathrm{C}_{4}$ 동위효소 및 이질사량체들은 나타나지 않았다(Fig. 3). 대사상 의 위치로 보아 주로 세포기질에 존재하는 것으로 알려져 있 는 $\mathrm{LDH}$ 가 미토콘드리아에서 나타난 점은 붕어, 갈겨니, 돌고 


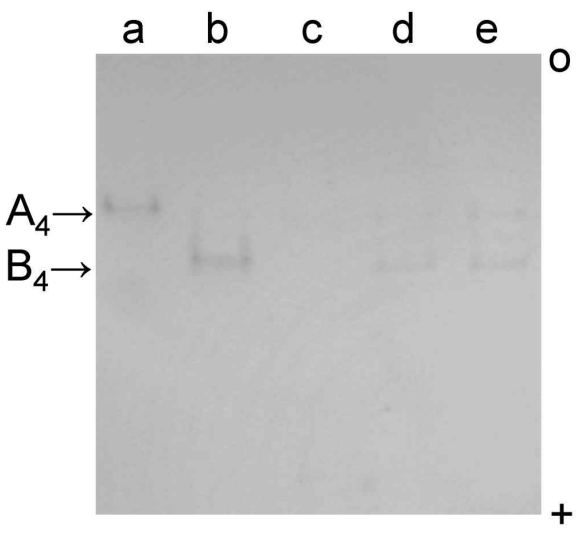

Fig. 3. Native-polyacrylamide gel electrophoresis zymograms of mitochondrial LDH isozymes in angelfish ( $P$. scalare). a, Skeletal muscle; $b$, heart; c, liver; $d$, eye; e, brain; $\mathrm{A}_{4}, \mathrm{LDH}$ $\mathrm{A}_{4}$ isozyme; $\mathrm{B}_{4}, \mathrm{LDH} \mathrm{B}_{4}$ isozyme; o, origin.

기, 참마자, 모래무지, 꺽지, 쏘가리, 얼룩동사리 및 자가사리 같은 다른 어류의 경우[6]와 같았다.

\section{환경 변화에 따른 조직별 LDH 활성의 변화}

Angelfish는 열대어이며 저산소 상태에 적응된 어류이다. 본 실험에서는 먼저 수조에서 $\mathrm{pH} 7 \pm 0.5$, 온도 $27 \pm 0.5^{\circ} \mathrm{C}$ 및 $\mathrm{DO}$ $6 \pm 1 \mathrm{ppm}$ 조건으로 순응시킨 후 환경변화를 주었다. 온도변화 조건은 기본조건에서 온도만 $18 \pm 0.5^{\circ} \mathrm{C}$ 로 급격히 낮추었고, $\mathrm{DO}$ 변화조건은 기본조건에서 $\mathrm{DO}$ 만 $6 \pm 1 \mathrm{ppm}$ 에서 $18 \mathrm{ppm}$ 으 로 변화를 주어 각각 수조안에서 2시간 적응시킨 후 각 조직의 $\mathrm{LDH}$ 활성 변화를 확인하였다(Table 2, 3, 4). 환경변화를 주지 않은 angelfish 각 조직에서 세포기질의 $\mathrm{LDH}$ 효소활성을 측 정한 결과 골격근 조직이 활성이 가장 많고 다음으로 심장, 눈, 뇌 및 간 조직의 순서로 나타났다(Table 2). 단백질양은 골격근 조직이 가장 많았고 뇌 조직이 가장 적게 나타났으며 심장, 간 및 눈 조직은 비슷한 양으로 나타났다(Table 2). 미토 콘드리아의 LDH 활성은 눈 및 뇌 조직만 바뀌었을 뿐 세포기 질의 $\mathrm{LDH}$ 활성과 유사한 순서로 나타났다(Table 2). 미토콘드 리아의 단백질양은 세포기질의 경우와 같이 골격근 조직이 다른 조직에 비해 높게 나타났다(Table 2). 온도를 $27 \pm 0.5^{\circ} \mathrm{C}$ 에 서 $18 \pm 0.5^{\circ} \mathrm{C}$ 로 급격히 낮추었을 때, 세포기질의 $\mathrm{LDH}$ 활성을 측정한 결과 골격근 조직의 $\mathrm{LDH}$ 활성이 가장 높게 나타났고 (Table 3), 골격근 및 심장 조직은 $27 \pm 0.5^{\circ} \mathrm{C}$ 에서 적응된 경우 보다 LDH 활성이 $1 / 3$ 정도로 낮게 나타났다(Table 2, 3). 단백 질 양은 간, 눈, 골격근, 심장 및 뇌 조직의 순서로 높게 나타났 고(Table 3$), 27 \pm 0.5^{\circ} \mathrm{C}$ 에서 적응된 것과 비교하였을 때 골격근 및 심장 조직에서 $\mathrm{LDH}$ 활성과 마찬가지로 현저히 떨어졌다 (Table 2, 3). 미토콘드리아의 $\mathrm{LDH}$ 활성을 세포기질의 $\mathrm{LDH}$ 활성과 비교한 결과 모든 조직에서 $\mathrm{LDH}$ 활성이 낮아졌지만 뇌 조직이 상대적으로 조금 감소되었고, 간 조직에서는 $\mathrm{LDH}$ 활성이 나타나지 않았다(Table 3). 온도를 낮추었을 때 미토콘
Table 2. LDH activities and protein concentrations of various tissues in angelfish $(P$. scalare during acclimation at basic condition ( $\mathrm{pH} 7 \pm 0.5$, Tem. $27 \pm 0.5^{\circ} \mathrm{C}$, DO $6 \pm 1 \mathrm{ppm}$ )

\begin{tabular}{lrc}
\hline & $\begin{array}{c}\text { Activity } \\
\text { (units/g) }\end{array}$ & $\begin{array}{c}\text { Protein concentration } \\
(\mathrm{mg} / \mathrm{g})\end{array}$ \\
\hline Cytosolic LDH & & \\
Skeletal muscle & 369.4 & 51.0 \\
Heart & 79.7 & 47.7 \\
Liver & 3.5 & 44.9 \\
Eye & 17.2 & 43.9 \\
Brain & 14.2 & 13.1 \\
\hline Mitochondrial LDH & & \\
Skeletal muscle & 8.7 & 3.3 \\
Heart & 7.2 & 0.6 \\
Liver & 2.8 & 1.5 \\
Eye & 5.3 & 1.7 \\
Brain & 6.9 & 0.8 \\
\hline
\end{tabular}

Table 3. LDH activities and protein concentrations of various tissues in angelfish $(P$. scalare) during acclimation at temperature condition (Tem. $27 \pm 0.5^{\circ} \mathrm{C} \rightarrow 18 \pm 0.5^{\circ} \mathrm{C}$ )

\begin{tabular}{lcc}
\hline & $\begin{array}{c}\text { Activity } \\
\text { (units/g) }\end{array}$ & $\begin{array}{c}\text { Protein concentration } \\
(\mathrm{mg} / \mathrm{g})\end{array}$ \\
\hline Cytosolic LDH & & \\
$\quad$ Skeletal muscle & 119.0 & 23.6 \\
Heart & 26.1 & 16.9 \\
Liver & 6.1 & 40.8 \\
Eye & 12.1 & 39.3 \\
$\quad$ Brain & 16.2 & 11.3 \\
\hline Mitochondrial LDH & & \\
$\quad$ Skeletal muscle & 0.6 & 0.97 \\
Heart & 0.8 & 0.04 \\
Liver & - & 9.04 \\
Eye & 0.3 & 2.58 \\
Brain & 4.3 & 1.97 \\
\hline
\end{tabular}

드리아의 $\mathrm{LDH}$ 활성 변화는 세포기질의 $\mathrm{LDH}$ 활성처럼 골격 근 및 심장 조직에서 많은 차이가 나타났고 단백질 양은 간, 눈 및 뇌 조직에서 증가되었다(Table 2, 3).

$\mathrm{DO} 6 \pm 1 \mathrm{ppm}$ 에서 순응된 angelfish를 DO $18 \mathrm{ppm}$ 의 환경 에 급작스럽게 순응시킨 후 각 조직의 $\mathrm{LDH}$ 활성 변화를 측정 하였다(Table 4). Angelfish 각 조직의 세포기질 LDH 활성을 측정한 결과 활성의 강도는 골격근, 심장, 뇌, 눈 및 간 조직 순서로 나타나 온도변화 시와 같은 순서로 나타났으며, 단백 질 양이 모든 조직에서 감소한 것도 온도변화 시의 경향과

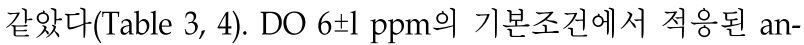
gelfish와 비교하였을 때, 심장 조직의 단백질 양은 감소하고 $\mathrm{LDH}$ 활성은 두 배 정도 높게 나타났다. 또한 눈 조직의 $\mathrm{LDH}$ 활성은 유사하고 뇌 조직의 활성은 증가되었다(Table 2, 4). $\mathrm{DO}$ 증가 시 angelfish 심장 및 뇌 조직에서 $\mathrm{LDH}$ 활성이 증가 
Table 4. LDH activities and protein concentrations of various tissues in angelfish ( $P$. scalare) during acclimation at DO condition $(6 \pm 1 \mathrm{ppm} \rightarrow 18 \mathrm{ppm})$

\begin{tabular}{lcc}
\hline & $\begin{array}{c}\text { Activity } \\
\text { (units/g) }\end{array}$ & $\begin{array}{c}\text { Protein concentration } \\
\text { (mg/g) }\end{array}$ \\
\hline Cytosolic LDH & & \\
Skeletal muscle & 298.8 & 36.2 \\
Heart & 141.3 & 29.7 \\
Liver & 3.0 & 34.4 \\
Eye & 17.8 & 29.0 \\
Brain & 20.7 & 11.4 \\
\hline Mitochondrial LDH & & \\
Skeletal muscle & 4.3 & 2.94 \\
Heart & - & - \\
Liver & 0.5 & 2.98 \\
Eye & 1.1 & 2.88 \\
Brain & 4.9 & 1.61 \\
\hline
\end{tabular}

된 결과는 메기[21] 및 모래무지[8]의 경우와 같았고 이는 호기 적 조직인 심장 및 뇌 조직의 $\mathrm{LDH}$ 동위효소가 산소농도에 의해 영향을 받음을 시사해 준다. 단백질양은 골격근, 간, 심 장, 눈 및 뇌 조직의 순서로 나타났다(Table 4). 미토콘드리아 $\mathrm{LDH}$ 의 효소활성을 세포기질 $\mathrm{LDH}$ 의 활성과 비교한 결과는 모든 조직에서 세포기질보다 낮게 나타났고 특히 심장 조직은 활성이 나타나지 않았다(Table 4). 뇌 조직의 경우 $\mathrm{LDH}$ 활성 이 다른 조직에 비해 비교적 높은 비율로 남아있어 변화가 적은 것으로 나타났고 단백질양은 모든 조직에서 세포기질보 다 낮게 나타났다(Table 4). 저온으로 온도변화를 주고 세포기 질의 $\mathrm{LDH}$ 활성을 측정 할 때 골격근 및 심장 조직에서 현저하 게 $\mathrm{LDH}$ 활성의 감소를 보이는 점은 온도변화에 따른 angelfish 운동성의 변화라고 추정되며 이에 관한 다른 종들에서의 연구가 더 필요할 것으로 사료된다.

\section{References}

1. Almeida-Val, V. M. F., M. N. Paula-Silva, W. P. Duncan, N. P. Lopes, A. L. Val, and S. Land. 1999. Increase of anaerobic potential during growth of an Amazonian cichlid, Astronotus ocellatus. survivorship and LDH regulation after hypoxia exposure, pp. 437-448, In Val, A. L. and V. M. F. Almeida-Val (eds.), Biology of Tropical Fishes. INPA, Mamaus.

2. Almeida-Val, V. M. F. and A. L. Val. 1993. Evolutionary trends of LDH isozymes in fishes. Comp. Biochem Physiol. $B$ 105, 21-28.

3. Basaglia, F. 1991. Lactate dehydrogenase isozymes and their genetic variation in fifteen Sparidae species(Perciformes, Teleostei). Comp. Biochem Physiol. B 98, 1-8.

4. Bradford, M. M. 1976. A rapid and sensitive method for the quantitation of microgram quantities of protein utilizing the principle of protein-dye binding. Anal. Biochem 72,
248-254.

5. Cahn, R. P., N. O. Kaplan, L. Levine, and E. Zwilling. 1962. Nature and development of lactate dehydrogenase. Science 136, 962-969.

6. Cho, S. K. 2000. Mitochondrial lactate dehydrogenase in tissues of vertebrate. Ph. D. Thesis, Cheongju University, Cheongju, Korea.

7. Cho, S. K., B. Ku, H. An, E. M. Park, S. Y. Park, J. B. Kim, and J. J. Yum. 2009. Purification and characterization of lactate dehydrogenase $\mathrm{A}_{4}$ isozyme in mandrin fish (Siniperca scherzeri). J. Life Sci. 19, 256-263.

8. Cho, S. K. and J. J. Yum. 2005. Changes of activities and isozymes of lactate dehydrogenase in Coreoperca herzi and Pseudogobio esocinus acclimated to rapid increase of dissolved oxygen. J. Life Sci. 15, 71-79.

9. Davis, B. J. 1964. Disc electrophoresis- П. Method and application to human serum proteins. Ann. N.Y. Acad Sci. 121, 404-427.

10. Feller, G., J. P. Pauly, A. Smal, P. O'Carra, and C. Gerday. 1991. The lactate dehydrogenase of the icefish heart: biochemical adaptations to hypoxia tolerance. Biochem Biophys. Acta 1079, 343-347.

11. Goldberg, E. 1972. Amino acid composition and properties of crystalline lactate dehydrogenase $X$ from mouse testes. J. Biol. Chem 247, 2044-2048.

12. Guderley, H. 1998. Temperature and growth rates as modulators of the metabolic capacities of fish muscle, pp. 58-87, In Portner, H. O. and R. C. Playle (eds.), Cold Ocean Physiology. Cambridge Univ. Press, Cambridge.

13. Guillemin, K. and M. A. Krasnow. 1997. The hypoxic response: Huffing and HIFing. Cell 89, 9-12.

14. Hardewig, I., P. L. N. Van Dijk, S. C. Leary, and C. D. Moyes. 2000. Temporal changes in enzyme activity and mRNA levels during thermal challenge in white sucker. Journal of Fish Biology 56, 196-207.

15. Hazel, J. R. and C. L. Prosser. 1974. Molecular mechanisms of temperature compensation in poikilotherms. Physological Reviews 54, 620-677.

16. Hochachka, P. W. and G. N. Somero. 1984. Biochemical adaptation. pp. 537, Princeton Univ. Press, Princeton.

17. Holt, R. W. and W. S. Leibel. 1987. Coexpression of distinct eye- and liver-specific LDH isozymes in Cilchlid fish. J. Exp. Zool. 224, 337-343.

18. Kepes, K. L. and G. S. Whitt. 1972. Specific lactate dehydrogenase gene functon in the differentiated liver of Cyprinid fish. Genetics 71, 5-29.

19. Kettler, M. K. and G. S. Whitt. 1986. An apparent progressive and recurrent evolutionary restriction in tissue expression of a gene, the lactate dehydrogenase-C gene, within a family of bony fish (Salmoniformes: Umbridae). J. Mol. Evol. 23, 95-107.

20. Kim, M. O. and J. J. Yum. 1989. Purification, kinetics and immunochemistry of two homotetrameric lactate dehydrogenase isozymes in Pseudogobio esocinus (Cypriniformes). Korean J. Zool. 32, 420-428.

21. Kim, J. B. and J. J. Yum. 1997. Acclimation of lactate de- 
hydrogenase in Silurus asotus to acute environmental variations. J. Ind Sci., Cheongju Univ., Korea. 15, 381-388.

22. Klyachko, O. S. and N. D. Ozernyuk. 1994. The effect of temperature on the kinetic properties of lactate dehydrogenase from embryos of various fish species. Comp. Biochem Physiol. B 107, 593-595.

23. Markert, C. L. 1984. Lactate dehydrogenase-biochemistry and function of lactate dehydrogenase. Cell Biochem Function 2, 131-134.

24. Markert, C. L., J. B. Shaklee, and G. S. Whitt. 1975. Evolution of a gene: multiple genes for $\mathrm{LDH}$ isozymes provide a model of the evolution of gene structure, function and regulation. Science 189, 102-114.

25. Martinez, G., P. Behrens, and Z. Coppes. 1994. $\mathrm{pH}$ and temperature influences on the $\mathrm{Km}$ values of $\mathrm{LDH}$ A4 from white muscles of two eurythermal sciaenid fishes. Comp. Biochem Physiol. B 107, 645-648.

26. Mendiola, P. and J. De Costa. 1991. The effects of temperature and $\mathrm{pH}$ on the kinetic properties of heart muscle lactate dehydrogenase from anuran amphinians. Comp. Biochem Physiol. B 98, 529-534.

27. Ozernyuk, N. D., O. S. Klyachko, and E. S. Polosukhina. 1994. Acclimation temperature affects the functional and structural properties of lactate dehydrogenase from fish (Misgurnus fossilis) skeletal muscles. Comp. Biochem Physiol. $B$ 107, 141-145.

28. Pahl, H. L. and P. A. Baeuerle. 1994. Oxygen and the control of gene expressin. Bioessays 16, 497-502.

29. Panepucci, L. L. L., M. L. Schwantes, and A. R. Schwantes. 1984. Loci that encode the lactate dehydrogenase in 23 species of fish belonging to the orders Cypriniformes, Siluriformes and Perciformes: adaptive features. Comp. Biochem Physiol. B 77, 867-876.

30. Park, S. Y. and J. J. Yum. 1993. Lactate dehydrogenase isozymes of Cypriniform and Perciform fishes: Expression of the Ldh-C gene. J. Ind Sci., Cheongju Univ., Korea. 11, 265-277.

31. Prosser, C. L. 1991. Temperature, pp. 109-165, In Prosser, C. L. (ed.), Comparative animal physiology, 4th eds.
Environmental and metabolic animal physiology. Wiley-Liss Inc., New York.

32. Russell, J. B. and K. L. Robyn. 1999. Hypoxic repressoin of lactate dehydrogenase-B in retina. Exp. Eye Res. 69, 685-693.

33. Schnaitman, C., V. G. Erwin, and J. W. Greenawalt. 1967. The submitochondrial localization of monoamine oxidase. J. Cell Bio. 32, 719-735.

34. Segal, J. A. and D. L. Crawford. 1994. LDH-B enzyme expression: the mechanisms of alterd gene expression in acclimation and evolutionary adaptation. Am J. Physiol. 267, 1150-1153.

35. Shaklee, J. B., J. A. Christiansen, B. D. Sidell, C. L. Prosser, and G. S. Whitt. 1977. Molecular aspects of temperature acclimation in fish: contributions of changes in enzyme activities and isozyme patterns to metabolic reorganization in the green sunfish. J. Exp. Zool. 201, 1-20.

36. Shaklee, J. B., K. L. Kepes, and G. S. Whitt. 1973. Specialized lactate dehydrogenase isozymes: the molecular and gentic basis for the unique eye and liver LDHs of teleost fishes. J. Exp. Zool. 185, 217-240.

37. Shaklee, J. B. and G. S. Whitt. 1981. Lactate dehydrogenase isozymes of Gadiform fishes: divergent patterns of gene expression indicate a heterogeneous taxon. Copeia 3, 563-578.

38. Skidmore, A. and T. J. C. Beebee. 1991. Changes in testicular lactate dehydrogenase of the rat (Rattus norvegicus) during growth and developmant. Comp. Biochem Physiol. B 98, 279-282.

39. Somero, G. N. 1997. Proteins and temperature. Annual Reviews of Physiology 57, 43-68.

40. Tsukuda, H. 1982. Effect of temperature on the red and white muscle lactate dehydrogenase of thermally acclimated goldfish. Comp. Biochem Physiol. B 73, 607-611.

41. Val, A. L. and V. M. F. Almeida-Val. 1995. Fishes of the Amazon and Their Environment. pp. 55-56, Springer-Verlag, Berlin.

42. Whitt, G. S. 1970. Developmental genetics of the lactate dehydrogenase isozymes of fish. J. Exp. Zool. 175, 1-35. 


\section{초록 : 급격한 환경변화에 대한 angelfish (Pterophyllum scalare) 젖산탈수소효소 동위효소의 변화}

안창수 $^{\dagger} \cdot$ 조성규 ${ }^{1 \dagger} \cdot$ 염정주 $^{2}{ }^{\star}$

(SK케미칼 생명과학사업본부 품질보증팀, ${ }^{1}$ 청주대학교 산업과학연구소, ${ }^{2}$ 청주대학교 자연과학부 생명과학 전공)

열대 저산소 환경에 적응되어 있는 angelfish (Pterophyllum scalare)를 급격한 온도변화 $\left(27 \pm 0.5 \rightarrow 18 \pm 0.5^{\circ} \mathrm{C}\right.$ ) 및 $\mathrm{DO}$ 변화 $(6 \pm 1 \rightarrow 18 \mathrm{ppm})$ 에 2시간 동안 적응시킨 후 젖산탈수소효소(EC 1.1.1.27, lactate dehydrogenase, $\mathrm{LDH}$ ) 동위 효소의 특성 및 유전자발현을 연구하였다. $\mathrm{LDH}$ 동위효소의 특성은 native-polyacrylamide gel 전기영동, Western blot 분석 및 효소활성 측정으로 확인하였다. 전기영동 결과 liver- 및 eye-specific $L d h-C$ 유전자는 간, 눈 및 뇌 조직에서 발현되었다. Western blot 분석 결과 $\mathrm{LDH} \mathrm{A} \mathrm{A}_{4}$ 동위효소는 $\mathrm{B}_{4}$ 동위효소보다 음극 쪽에 나타났다. 간 조직에 서 온도 저하 시 $\mathrm{LDH} \mathrm{A} \mathrm{A}_{4}$ 동위효소가 증가하고 $\mathrm{B}_{4}$ 동위효소는 감소하였으며, $\mathrm{DO}$ 증가 시 $\mathrm{LDH} \mathrm{A} \mathrm{A}_{4}$ 및 $\mathrm{C}_{4}$ 동위효소가 증가하고 $\mathrm{B}_{4}$ 동위효소는 감소하였다. 눈 조직에서는 온도 저하 시 $\mathrm{LDH} \mathrm{A} \mathrm{A}_{4}$ 및 $\mathrm{B}_{4}$ 동위효소가 증가하고 $\mathrm{C}_{4}$ 동위효소는 감소하였으며, $\mathrm{DO}$ 증가 시 $\mathrm{LDH} \mathrm{A} 4$ 및 $\mathrm{B}_{4}$ 동위효소는 증가하지만 $\mathrm{C}_{4}$ 동위효소 및 하부단위체 $\mathrm{C}$ 를 포함하는 동위효 소는 감소하였다. 심장 조직에서는 $\mathrm{DO}$ 증가 시 $\mathrm{LDH}$ 활성이 증가하였고, $\mathrm{LDH} \mathrm{B} \mathrm{B}_{4}$ 동위효소가 증가하였다. 뇌 조직에서는 온도 저하 시 $\mathrm{LDH} \mathrm{A} \mathrm{A}_{4}$ 및 $\mathrm{B}_{4}$ 동위효소가 증가하였고, $\mathrm{DO}$ 증가 시 $\mathrm{LDH} \mathrm{B}_{4}$ 동위효소는 증가하였다. 따라서 liver- 및 eye-specific $L d h-C$ 는 DO 변화에 의해 영향을 받으며 간 및 눈 조직에서 $\mathrm{LDH} \mathrm{B}_{4}$ 및 $\mathrm{C}_{4}$ 동위효소는 서로 상대적으로 조절되므로 $\mathrm{C}_{4}$ 동위효소는 lactate oxidase로서 기능을 나타내는 것으로 사료된다. 